\title{
Quality assessment of structural steel in mining equipment manufacture
}

\author{
Aleksandr Korotkov, ${ }^{1, *}$, and Lidia Korotkova ${ }^{1}$ \\ ${ }^{1}$ Kuzbass State Technical University, Department metal-cutting, machines and tools, 650000, Kemerovo, Russian Federation
}

\begin{abstract}
The relevance of this work is to form a methodical, scientific-based approach and the application of this experience in solving problems of quality control and improvement, as well as to identify ways of eliminating defects and small lifetime of the materials, used in critical parts and units of mining equipment. The aim of scientific research of the article is the study of discrepancy of structural steels quality problem, used for the manufacture of parts and components of mining equipment, established by standards. The goals are also, development and practical application of quality control methods in delivery condition and at all main stages of parts manufacture in accordance with the current state standards. As a result of steel quality complex control in delivery condition, it was possible to identify: the deviation of the chemical composition of steels and alloys, macrodefects, microdefects, deviation in hardness. Practical recommendations to eliminate and reduce and prevent the defects in parts and units used in mining engineering were developed. The paper presents practical experience in evaluation the quality of construction materials, which may be useful in design, manufacture and operation of mining industry and related manufacture industries.
\end{abstract}

\section{Introduction}

High demands are maintained to the reliability of mining equipment parts and one of the main issues of this demand is that the quality of the materials used must be established by standards. Technological control of steels and alloys in mining industry enterprises is an obligatory element of management system of goods quality, the task of the system is to prevent the release of defective goods.

In recent years, the problem of relevance of metals quality correspondence to the established standards increased. Its solution is possible through the creation of laboratories with modern metallographic equipment, training of qualified staff and the development of necessary methodical support to control materials quality.

The KuzSTU department "Metal-cutting machines and tools" studied some aspects of this problem on the example of steels and alloys quality assessment used in enterprises of Kuzbass coal mining, and the ways of its solution were suggested. The correlation of intense mining equipment parts wear with the quality of metal was studied; and recommendations for repair, recovery and work life extension of machine parts for such goods were developed.

\section{Materials and Methods}

In the course of the research the method of structural steels quality control used in mining engineering was developed and implement. The method is based on the current state standards, and its application allows to solve the problem of provision of the required characteristics for the parts of mining equipment.

The method of steel quality control on the basic parameters of the microstructure is shown in Table 1.

Steels quality control should include the following basic steps:

- structural steel quality control in delivery condition for compliance with standards of the following parameters: visual and measuring control, chemical analysis, mechanical and technological tests, metallographic tests;

-analysis of thermal processing at all major technological stages of production, the development of recommendations for the initial heat treatment to eliminate the defects of the microstructure, the adjustment of hardening heat treatment in order to ensure the necessary properties to complex parts and goods;

- recommendations' formulation for rejecting defected metal parcels on the basis of their quality control results in delivery condition.

After visual and measuring control of steels their chemical analysis is carried out, since it is the main characteristic.

In particular, the full range of physical, mechanical and technological properties of steels depends on the content of chemical elements and chemical impurities. Macroanalysis is also an important step in steels quality control, it allows to assess the quality of the metal and its previous processing, affecting the property of metal under heat treatment during subsequent processing. Microanalysis reveals structural defects as in delivery

* Corresponding author: korotkov.a.n@mail.ru 
condition and also at the stages of initial and hardening heat treatment. Indicators of metals mechanical properties are measured according to the strength, hardness, relevant elongation, contraction, toughness and etc.

Table 1. The main parameters of the microstructure and control conditions of structural steels quality

\begin{tabular}{|c|c|c|}
\hline 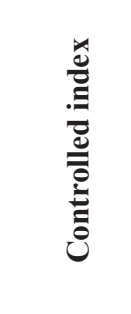 & 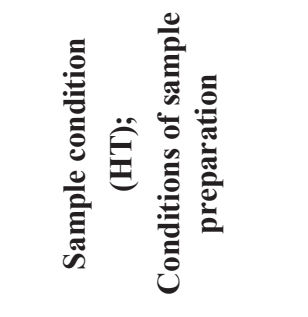 & 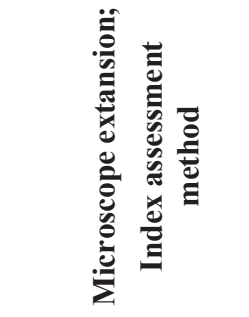 \\
\hline 1 & 2 & 3 \\
\hline $\begin{array}{l}\text { Decarbo } \\
\text { nized } \\
\text { layer }\end{array}$ & $\begin{array}{l}\text { Heat treatment; } \\
\text { Polishing in } \\
\text { diametral plane } a^{*} \text {; } \\
\text { etching operation by } \\
2-4 \% \text { alcoholic } \\
\text { solutionn } \mathrm{HNO}_{3}\end{array}$ & $\begin{array}{l}100^{\times} \\
\text {and more; } \\
\text { Measurement by } \\
\text { ocular ruler on } \\
\text { two samples on } \\
\text { GOST } 9012, \\
\text { allowed } 2 \% \times d \text {, } \\
\text { not more }\end{array}$ \\
\hline $\begin{array}{l}\text { Pearlite } \\
\text { microstr } \\
\text { ucture }\end{array}$ & $\begin{array}{l}\text { Heat rolled, annealed } \\
\text { Polishing in } \\
\text { diametral plane } a^{*} \text {; } \\
\text { etching operation } \\
2-4 \% \text { alcoholic } \\
\text { solution } \mathrm{HNO}_{3}\end{array}$ & $\begin{array}{c}500^{\times} \\
(450-600) ; \\
\text { Comparison with } \\
\text { the standard scale } \\
\text { on GOST 9454, } \\
\text { allowed grade } 4 \text {, } \\
\text { not more }\end{array}$ \\
\hline $\begin{array}{l}\text { Carbide } \\
\text { network }\end{array}$ & $\begin{array}{c}\text { Heat treatment; } \\
\text { Polishing in } \\
\text { diametral plane } a^{*} ; \\
\text { etching operation 2-4\% } \\
\text { alcoholic solution } \\
\mathrm{HNO}_{3}\end{array}$ & $\begin{array}{c}100^{\times} \\
\text {and more; } \\
\text { Comparison with } \\
\text { the standard scale } \\
\text { on GOST 9454, } \\
\text { allowed grade 3, } \\
\text { not more }\end{array}$ \\
\hline $\begin{array}{l}\text { Carbide } \\
\text { segregati } \\
\quad \text { on }\end{array}$ & $\begin{array}{c}\text { Heat treatment; } \\
\text { Polishing in } \\
\text { diametral plane } a^{*} ; \\
\text { etching operation } 2-4 \% \\
\text { alcoholic solution } \\
\mathrm{HNO}_{3}\end{array}$ & $\begin{array}{l}90-110^{\times ;} \\
\text {Comparison with } \\
\text { the standard scale, } \\
\text { allowed grade } \\
1-2, \text { not more }\end{array}$ \\
\hline $\begin{array}{l}\text { Banded } \\
\text { orientati } \\
\text { on }\end{array}$ & $\begin{array}{c}\text { Non annealed state; } \\
\text { Polishing in } \\
\text { diametral plane } 8^{* *} ; \\
\text { etching operation } 24 \% \\
\text { alcoholic solution } \mathrm{HNO}_{3}\end{array}$ & $\begin{array}{c}90-110^{\times} ; \\
\text {Comparison with } \\
\text { the standard scale } \\
\text { on GOST } 1763 \text {, } \\
\text { allowed grade } \\
2-3, \text { nor } \\
\text { more }\end{array}$ \\
\hline $\begin{array}{l}\text { Microp } \\
\text { orocity }\end{array}$ & $\begin{array}{l}\text { Heat treatment; } \\
\text { Polishing in } \\
\text { diametral plane } a^{*}\end{array}$ & $\begin{array}{l}90-110^{\times} ; \\
\text {Comparison with } \\
\text { the standard scale, } \\
\text { allowed grade } 2, \\
\text { not more }\end{array}$ \\
\hline
\end{tabular}

\begin{tabular}{|c|c|c|}
\hline 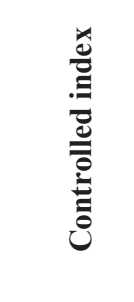 & 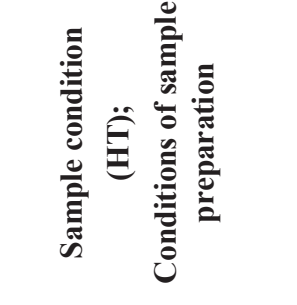 & 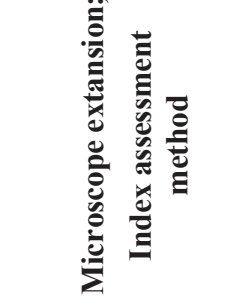 \\
\hline 1 & 2 & 3 \\
\hline $\begin{array}{l}\text { Nonmeta } \\
\text { lic } \\
\text { inclinati } \\
\text { ons }\end{array}$ & $\begin{array}{l}\text { Heat treatment } \\
\text { Polishing in } \\
\text { diametral plane } a^{*}\end{array}$ & $\begin{array}{c}90-110^{\times} \text {; } \\
\text { Comparison of the } \\
\text { most contaminated } \\
\text { place with the scales } \\
1,2,3 \text { of standard } \\
\text { on GOST } 8233 \text {, } \\
\text { allowed grade } \\
2-3, \text { not more }\end{array}$ \\
\hline $\begin{array}{l}\text { Grain } \\
\text { size }\end{array}$ & $\begin{array}{l}\text { Heat rolled, annealed; } \\
\text { Polishing in } \\
\text { diametral plane; } \\
\text { etching operation to } \\
\text { blackening }\end{array}$ & $\begin{array}{c}100^{\times} \\
200^{\times} \\
400^{\times} ; \\
\text {Method according } \\
\text { to grain size. The } \\
\text { grades on the } \\
\text { scale of the } \\
\text { standard on } \\
\text { GOST 5640, } \\
\text { allowed grade } \\
6-8, \text { not lower }\end{array}$ \\
\hline
\end{tabular}

\section{Results and Discussion}

As the examples of the application of the developed steels quality control method the practical experience of such developments for the Kuzbass enterprises is shown.

In the course of development of production of hydraulic roof supports the problem

of low strength cylinder was discovered. To eliminate it, the complex of the following activities was done:

- structural steel used for the manufacture of hydraulic cylinders was explored;

- deviations from the standard indicators were determined;

- hardening heat treatment to provide the required mechanical properties of goods was designed;

- recommendations were developed of initial heat treatment in order to remove defects and to provide the desired technological properties of steel in delivery condition.

Chemical analysis allowed identifying the supplied steels for compliance with steel grades. It was found that these heat rolled steel pipes are made from steels 45, $30 \mathrm{ChGSA}$ and $35 \mathrm{Ch}[1,2]$. According to the basic elements the chemical composition of all steels was agreed with standards GOST 4543 [3], but unacceptable overstated sulfur content was found in these steels.

Metallurgical studies (Table 1) include an assessment of contamination by nonmetallic inclusions, grain size determination, banded orientation, microstructure research (on GOST 8233, GOST 5639, GOST 1778) [4]. 
Microstructure researches have shown the difference in heat treatment of steel in delivery condition: pipes from steel 45 are normalized heat rolled ones with ferrite pearlitic structure. Pipes from 35ChGSA steel and steel $35 \mathrm{Ch}$ are an improved heat rolled ones with the structure of granular sorbite (on GOST 4543, GOST 10243) [5, 6, 7].

In some parcels of pipes from steel 45 defective overheated structures were found with signs of widmanstatt with unacceptable grain size corresponding to the 5 th grade. In the pipes from steel $35 \mathrm{Ch}$ the defect of structures was found - it is the inclusion of graphite in the structure of sorbite. In all parcels the defects were found in the form of non-metallic inclusions with admissible limit values (on GOST 1778) [8,9].

Thus, metallographic studies indicate the low quality of the metal in delivery condition.

In the results of the complex control the company was recommended:

-to use air-hardening as initial heat treatment, and to use refining as strengthening treatment - that will provide the desired mechanical complex of properties to hydraulic cylinders (on GOST 9012, GOST 9454, GOST 1497);

-to organize systematic complex quality control of steels in the enterprise;

-to correct thermal treatment, taking into account monitoring results.

Another example of the developed method application relates to the production of a drilling tool. In particular, the problems associated with low-strength of holders of worm cutting tools from steel 35ChGSA were studied $[10,11,12,13]$.

The researches were carried out at the main stages of the production process: after forging with various variants of initial heat treatment and after strengthening heat treatment.

Quality control of steel was carried out in accordance with GOST 4543. The presence of non-metallic inclusions, pores, flakes, forging cracks was investigated. The microstructure was studied at all major stages of the heat treatment process. The analysis was conducted using a metallographic studies and microhardness measurements. The fracture character of cutting tools was determined by fractures type, received in the result of the destruction of a tool during operation under actual production conditions.

Blanking operation consisted of forging and subsequent heat treatment. The working part of the cutting tool holder was subjected to forging, which was initially heated by high frequency currents (HFC). The temperature for the beginning and end of the forging was not controlled. After hot treatment by pressure two variants of initial heat treatment were used: I variant annealing (at $700{ }^{\circ} \mathrm{C}$ during 6 hours); II variant - refining (heat treatment at $880{ }^{\circ} \mathrm{C}$ in oil followed by blazing-off at $600{ }^{\circ} \mathrm{C}$ for 1.5 hours, cooling - air).

In microstructure of the forged sample a number of unacceptable defects was identified: large grain (3-4 grades); widmanstatten structure; ferrite network; the presence of flakes, non-metallic inclusions above the admittible limits $[4,5,6,7]$.
The results of microstructure studies and measurement of microhardness of testify to the heterogeneity of microstructure and hence to the irregularity of properties along the axis of the cutting tool holder. Here there are three distinct zones. The first zone is located directly in the cutter head (up to the depth of $10 \mathrm{~mm}$ ), it has a characteristic structure of overheated steel in the form of widmanstatten structure. The second zone is transitional and extremely heterogeneous (with the depth of 10 to $25 \mathrm{~mm}$ ); it includes large size grain ferrite pearlitic structure with ferrite network along grain boundary with inclusions of sorbitic pearlite. The third zone is located in the tail of the cutting tool (at a distance of $25 \mathrm{~mm}$ ), refers to a nondeformable section of the sample and has a fine grain ferrite pearlite structure of normalize steel. The heterogeneity of the microstructure in the forged sample is confirmed by microhardness measurements.

Thus, on the basis of technological inheritance studies, based on the structure researches, microhardness measurements, analysis of fractures [12,13], the adjustment has been made in heat treatment of worm of the cutting tool from steel 35ChGSA:

-in the capacity of initial heat treatment, it is recommended to apply a complete annealing (840-860 ${ }^{0} \mathrm{C}$ ), that allowed to obtain homogeneous structure along the whole length of the cutter, to remove defects in the structure (large grain, structural heterogeneity), acquired at the stage of forging;

- in the capacity of strengthening heat treatment it is recommended to apply blazing-off $\left(250{ }^{\circ} \mathrm{C}\right)$ after heat treatment $\left(880^{\circ} \mathrm{C}\right)$ with rapid cooling in oil, instead of the average, which improves the toughness of the steel (1-1.2 $\mathrm{mJ} / \mathrm{m} 3)$;

-the enterprise was recommended to increase the requirements to the supplier because of the low quality of supplied steel, associated with unacceptably large number of non-metallic inclusions and the presence of harmful flakes in the microstructure.

The parts wear of a high-pressure pump (70-90 atmospheres) was also investigated (the pump is used by coal mining enterprises), due to high wear and tear of its parts, and rapid failure of the whole pump mechanism. The object of the study was the leading pump shaft and gears, front infill plates and a plain bearing line. As a result of metallographic tests, it was estimated that the shaft is made of low carbon steel containing $0.178 \%$ of carbon, and it is alloyed with $1.058 \%$ manganese and $0.940 \%$ chromium. The analogue of such steel is a national steel grade $18 \mathrm{ChG} \mathrm{GOST} 4543$ [3].

Thermal processing of a shaft provides the hardness 57-59 HRC. The microstructure of the shaft over the entire section consists of a low-carbon martensite. The structure of landing part of the shaft is heterogeneous: the shaft core is composed of ferrite pearlitic normalized structure, and in the zone of contact with the gear the hardness is 51-53 HRC, which corresponds to the martensite structure [4].

The gear is made of high carbon steel type Ch, ShCh15. It is heat treated for maximum hardness of 6064 HRC. The microstructure consists of martensite and derived carbide inclusions which are distributed 
uniformly and have a dispersed structure with a size of 1-2 microns. The layer of ferrite fine grained steel is rolled on the outline of the gear surface. The layer thickness is $0.08-0.10 \mathrm{~mm}$.

Studies of front infill plates of a pump showed that they are made of carbon-free ferrite steel and their surface is coated with a layer of powders of cast tin bronze. The powder on the infill plate is sprayed [14, 15]. Analogs of these bronzes can be done from national tin bronze of Br05S25 Br08S12 grades according to GOST 613-79.

As a result of the research and determined chemical composition of the pump parts, it becomes possible to manufacture them from national materials mentioned above.

\section{Conclusion}

As a result of this research, the following conclusions can be formulated:

1. There is a problem with low-quality steel goods in delivery condition (metal deviations according to chemical composition, the macroscopic defects presence, the defects presence in the microstructure, mechanical properties discrepancy), which is projected to enterprises of mining engineering.

2. A method of steel quality control in delivery condition and during manufacturing process of parts was developed, contributing to the improvement of the quality, and therefore provision of the specified performance characteristics of the various engineering goods under the manufacture of mining equipment.

3. Due to the metals quality control (in particular, the establishment of their chemical composition and heat

treatment features), it is possible to repair and restore the parts and goods of foreign production from national metals and alloys.

4. In general, it should be mentioned that the metal quality control problem is becoming increasingly important and to solve it the factory laboratories should be developed, or centralized laboratories should be created (e.g., on the basis of technical institutes) which are capable to solve such alloy sheet during rolling. Structural materials: properties, microstructure and processing.

\section{References}

1. Y.P. Solntsev. Metals and alloys. Reference book. (ANO NPO Professional, St. Peterburg, 2003)

2. A.S. Zubchenko. Database of steels and alloys. (Mechanical engineering, Moscow, 2001)

3. Handbook of steels. (Sendvikens Trykeri AB, Sweden, 2013)

4. H. Hiorns. Metallography ( An Introduction to the Study of the Structure of Metals, 2009)

5. G. Zlateva. Microstructure of Metals and Alloys: An Atlas of Transmission Electron Microscopy Images.

(Taylor\&Francis Group, 2008)
6. B. Bramfitt. Metallographer's Guide: Practices and Procedures for Irons and Steels. (ASM International, 2002)

7. E. Berghof-Hasselbächer. Atlas of Microstructures. (Main Germany, 2013)

8. M. Shtremel, MiTOM. 8, (1980)

9. M. Gergiev, MiTOM, 2, (1974).

10. L. Korotkova, MiTOM, 3, (1988)

11. G. Muchin, MiTOM, 4, (1982)

12. A. Amosov, Bulletin of universities. Ferrous metallurgy, 1, (2004)

13. S.-J. Kim, Structurual materials: properties microstructure and prosessing. (2014)

14. A. Korotkov, Applied Mechanics and Materials, 682 (2014)

15. M. Tuttle Structural Analysis of Polymeric Composite Materials. (Hardcover Book, 2007) 